\title{
Immunological reactions induced by bendamustine
}

\author{
Maria-Jose Sanchez-Gonzalez ${ }^{1 *}$, Jose Barbarroja-Escudero², Dario Antolin-Amerigo², Guadalupe Marco-Martin², \\ Melchor Alvarez-De-Mon ${ }^{3}$, Mercedes Rodriguez-Rodriguez ${ }^{2}$ \\ From 6th Drug Hypersensitivity Meeting (DHM 6) \\ Bern, Switzerland. 9-12 April 2014
}

\section{Introduction}

Bendamustine is being recently used as treatment of chronic lymphocytic leukemia (CLL) and B-cell nonHodgkin lymphoma. There are just a few reported cases of adverse reactions to bendamustine so far, none of them with an allergological study.

\section{Method}

\section{Patient 1}

A 61-year old woman, diagnosed with B-cell CLL (BCLL) received bendamustine, tolerating the first cycle. Three weeks later, 8 hours after the 1st dose of the 2nd cycle, she suffered throat discomfort, pruritus, hives, general erythema and facial swelling; which disappeared within 24 hours after treatment.

\section{Patient 2}

A 61-year old man, diagnosed with B-CLL. Four years ago, he adequately tolerated bendamustine. One week after the first and well tolerated cycle, he received the second, and within 8-10 hours after the dose he developed a maculopapular exanthema, edema in arms and legs, along with desquamation of hands and feet, without residual lesions. Symptoms disappeared within the first two weeks.

\section{Patient 3}

A 63-year old man, diagnosed with B-CLL. Three hours after the infusion of the first and second cycles of bendamustine, he had a generalized tremor and fever of $39^{\circ} \mathrm{C}$. The symptoms ceased with acetaminophen $650 \mathrm{mg}$. One month later, 3 hours after the 3rd cycle of bendamustine, he had generalized tremor and erythema, dizziness and body temperature of $39^{\circ} \mathrm{C}$. Hypotension, paroxysmal atrial fibrillation and a mild renal failure were verified. The symptoms disappeared with acetaminophen $1 \mathrm{gr}$ and an adequate hydration.

\section{Results}

We performed skin-prick-test (SPT) at $1 \mathrm{mg} / \mathrm{ml}$ and intradermal testing (IDT) at 0.001, 0.01, 0.1 and $1 \mathrm{mg} /$ $\mathrm{ml}$, with immediate and delayed lectures (24h and $72 \mathrm{~h}$ ). As negative controls two B-CLL patients underwent SPT and IDT with negative results.

\section{Patient 1}

SPT was negative. IDT at 0.1 and $1 \mathrm{mg} / \mathrm{ml}$ were positive at $24 \mathrm{~h}$, being negative $72 \mathrm{~h}$ later. The rest of the tests were negative.

\section{Patient 2}

He had a negative SPT. The $24 \mathrm{~h}$ lectures of the IDT were positive at $0.01,0.1$ and $1 \mathrm{mg} / \mathrm{ml}$, remaining positive $72 \mathrm{~h}$ later. The rest of the tests were negative.

\section{Patient 3}

The SPT and IDT, both immediate and delayed lectures, were negative.

\section{Conclusion}

We report the first two cases of hypersensitivity to bendamustine with a positive result in the allergological study carried out, which demonstrated a delayed cutaneous hypersensitivity to bendamustine. We also report the first case of drug fever induced by bendamustine in clinical use, showing neither a type I nor a IV hypersensitivity mechanism to bendamustine.

${ }^{1}$ Principe De Asturias University Hospital, Spain

Full list of author information is available at the end of the article 


\section{Authors' details}

${ }^{1}$ Principe De Asturias University Hospital, Spain. ${ }^{2}$ Principe De Asturias

University Hospital, Allergy Department, Spain. ${ }^{3}$ Principe De Asturias

University Hospital, ESI Department, Spain.

Published: 18 July 2014

doi:10.1186/2045-7022-4-S3-P56

Cite this article as: Sanchez-Gonzalez et al:: Immunological reactions

induced by bendamustine. Clinical and Translational Allergy 2014

4(Suppl 3):P56.

Submit your next manuscript to BioMed Central and take full advantage of:

- Convenient online submission

- Thorough peer review

- No space constraints or color figure charges

- Immediate publication on acceptance

- Inclusion in PubMed, CAS, Scopus and Google Scholar

- Research which is freely available for redistribution

Submit your manuscript at 